\title{
GERMINATION AND EMERGENCE OF Stachytarpheta cayennensis AND Ipomoea asarifolia $^{1}$
}

\author{
MOACYR B. DIAS-FILHO ${ }^{2}$
}

\section{RESUMO}

\section{Germinação e emergência de Ipomoea asarifolia e Stachytarpheta cayennensis}

\begin{abstract}
O entendimento de como a germinação e eme rgência de plantas daninhas respondem a fatores ambientais é de grande importância para a determinação da capacidade de adaptação e potencial de infestação, podendo ainda auxiliar no desenvolvimento de práticas de controle eficazes. A germin ação de Ipomoea asarifolia (Desr.) Roem. \& Schultz e Stachytarpheta cayennensis (Rich) Vahl. diminuíram linearmente com o decréscimo do potencial osmótico do meio de germinação, sendo que o aumento do estresse os mótico atra sou com maior intensidade a germinação de Ipomoea do que a de Stachytarpheta. A germinação de Ipomoea foi insen sível à luz; já a de Stachytarpheta mostrou ter um comportamento fotoblástico positivo. $\mathrm{O}$ nitrato teve um efeito negativo na germinação de
\end{abstract}

Ipomoea sob condições de luz ou escuro, mas estimulou a germinação de sementes de Stachytarpheta no escuro. A emergência de Ipomoea não foi significativamente afetada pela profundidade de semeadura. No entanto, em Stachytarpheta, a emergência das plântulas foi restrita a sementes plantadas na superfície do solo. A emergência de plântulas de Ipomoea de prof undidades superiores a $6 \mathrm{~cm}$ ocasionou decréscimos significativos no percentual de biomassa alocada para as raízes, enquanto o percentual de biomassa alocado para as folhas decresceu para plântulas emergentes de profundidades superiores a $2 \mathrm{~cm}$.

Palavras chave: Nitrato, luz, estresse osmótico, profundidade de semeadura, gervão.

\begin{abstract}
Understanding how weed seed germination and emergence respond to environmental factors is critical to determining their adaptive capabilities and potential for infestation, and could also aid in the development of effective control practices. Germination of Ipomoea asarifolia (Desr.) Roem. \& Schultz and

Stachytarpheta cayennensis (Rich) Vahl. decreased linearly with decreasing os motic potentials. Also, increasing osmotic stress delayed germination of Ipomoea more than that of St achytarp heta. Ip om oe a ge rmin ation was

insensitive to light, while Stachytarpheta showed a positive photoblastic behavior. Nitrate had a negative effect on germination of Ipomoea seed und er both light and dark condition s but stimulated dark germination of Stachytarpheta. Ipomoea emergence was not significantly affected by planting depth. However, for Stachytarpheta emergence was restricted to seeds planted at the soil surface. Emergence of Ipomoea seedlings from greater than $6 \mathrm{~cm}$ significantly decreased the amount of biomass allocated to roots, while biomass allocated to leaves was decreased for
\end{abstract}

1Received for publication on 19/01/96 and in the revised form on 18/02/97.

2Research agronomist, Ph.D., Lab. Ec of is iologia Vegeta1, EMBRAPA/CPATU, Cai xa Postal 48, CEP 66017 -970, Belém-PA, Brazil, e-mail: moacyr@marajo.ufpa.br. 
seedlings that emerged from depths greater than $2 \mathrm{~cm}$. These germination and emergence responses are discussed in relation to their ecological

\section{INTRODUCTION}

Knowledge of the seed germination requirements of weed species can be relevant to both agronomic and ecological perspectives. For example, much of the loss of seeds from the soil (decline in soil seed bank) seems to be attributable to germination (Schafer \& Chilcote, 1970); therefore decline in the soil seed bank would be greatest under conditions favoring germination of specific species. The significance of seed germination to weed control programs can be stressed by the fact that, unlike dormant seeds that are often unaffected by most methods of weed control, germinating seeds are usually vulnerable. Thus, knowledge of germination patterns and the influence of environmental factors on seed germination is es sential for development of preventive weed control programs.

Ipomoea asarifolia, a member of the Convolvulaceae, and Stachytarpheta cayennensis, in the Verbenaceae, are important perennial weed y species from pastures and crop areas in Brazil (Dias Filho, 1990; Dias Filho, 1994; Dias Filho et al. 1995; Lorenzi, 1991). Although native to tropical America, S. cayennensis also occurs as a weed in Australia (Kleinschmidt \& Johnson, 1987), Hawaii (Haselwood \& Motter, 1983) and India (Nair et al., 1982). In addition, many Ipomoea species are also considered as troublesome weeds in warm temperate zones (Elmore et al., 1990).

No biological or ecological information is available on the environmental factors influencing seed germination and emergence of these species. Such information would enable the understanding of these species adaptive capabilities and their potential for infestation, and could also aid in the development of effective control practices. Because in tropical pasture and agricultural areas implications and to weed control strategies.

Key words: Nitrate, light, osmotic stress, depth of planting.

soil osmotic potential and nitrate levels can vary due to temporal changes in soil water availability, and the light environment can be extremely variable due to vegetation cover, it is important to know the germination response of tropical weed seeds to these factors. Also, in these environments soil cultivation and biotic agents may often change the position of weed seeds in the soil profile; hence, it is important to know the emergence response of weed seedlings to different planting depths. Therefore, the objectives of this research were to assess the effects of light, nitrate and os motic stress on seed germination of Ipomoea and Stachytarpheta, and to determine the effect of planting depth on seedling emergence and biomass allocation of the two species.

\section{MATERIALS AND METHODS}

Seeds of Ipomoea asarifolia and Stachytarpheta cayennensis were collected from pasture areas in Brazilian Amazonia. After collection, seeds were cleaned and stored in low humidity at room temperat ure until initiation of the experiments 6-10 months later.

\section{Osmotic stress}

The effect of osmotic stress on germination was assessed in water solutions with osmotic potentials of $-0.2,-0.4,-0.6,-0.8$ and -1.0 $\mathrm{MPa}$, prepared by dissolving appropriate amounts of polyethylene glycol (PEG 8000) in deionized water (Smith et al., 1992). Deionized water alone was used for the $0 \mathrm{MPa}$ standard in the experiment. Seeds were incubated in $9-\mathrm{cm}$ glass petri dishes with two sheets of filter paper (Whatman No. 1. Whatman International Ltd. Maid st one, England) in a grow th chamber (Percival, Model PT-80, Boone, IA) set at 12-h photoperiod and $31 / 24^{\circ} \mathrm{C}$ temperature regime. 
Each petri dish had 20 seeds and received $7 \mathrm{mI}$ of the appropriate solution. Solutions and filter papers were renewed every other day to minimize water potential change through time (Emmerich \& Hardegree, 1990). All petri dishes were sealed wi th a strip of Parafilm (Laboratory film. American National Can, Greenwich, CT). Prior to incubation, Ipomoea seeds were scarified with concentrated sulfuric acid for $20 \mathrm{~min}$ to overcome the hard seededness known to occur in th is species. Preliminary trials indicated that this period was ideal to break seed dormancy in this species (M. B. Dias Filho, unpublished data). By previously breaking seed dormancy, any delay in germination during the experimental period could be attributed to treatment effect and not to natural dormancy. Germination counts were made every two days for eight days for Ipomoea or 18 days for Stachytarpheta. These periods have previously been determined as around $20 \%$ above the ideal period for maximum germination for these species (M. B. Dias-Filho, unpublished data).

\section{Light and nitrate}

The effects of nitrate and light were determined in a growth chamber with temperature set at $31^{\circ} \mathrm{C}$ (d ay) and $24{ }^{\circ} \mathrm{C}$ (night), and a photoperiod of $12 \mathrm{~h}$. Fluorescent lighting provided a mean photosynthetic photon flux density (PPFD) of $200 \mu \mathrm{cool} \mathrm{m} \mathrm{m}^{-2}$. Two sets of 9-cm glass petri dishes lined with two filter papers received $7 \mathrm{ml}$ of either 0,5 or $10 \mathrm{mM}$ of $\mathrm{KNO}_{3}$. Deionized water alone was used for the $0 \mathrm{mM}$ standard. One set of petri dishes was wrapped in two layers of aluminum foil to exclude light. All petri dishes we re sealed with a strip of Parafilm. The experiment was concluded after seven days for Ipomoea and 14 days for Stachytarpheta and germination was determined.

\section{Planting depth}

Seeds from each species were planted in 15-cm-diam plastic pots on the soil surface and at depths of $1,2,4,6,8$, and $10 \mathrm{~cm}$. Pots were filled with $250 \mathrm{~g}$ (air dry weight) of a potting soil 120 placed in a greenhouse with temperatures ranging from $33 \pm 2.1^{\circ} \mathrm{C}$ during the day to $24 \pm 2.2^{\circ} \mathrm{C}$ at night. In addition to natural light, $400 \mathrm{~W}$ lamps extended day length to $12 \mathrm{~h}$ and maintained PPFD, measured at the soil surface, at about $900 \mu \mathrm{mol} \mathrm{m}$ ${ }^{2} \mathrm{~S}^{-1}$. The soil was initially irrigated to saturation, then watered daily from the top. Ten or five seeds per pot were planted, respectively for Stachytarpheta and Ipomoea. Prior to planting Ipomoea seeds were scarified with concentrated sulfuric acid for $20 \mathrm{~min}$. Emergence counts were recorded daily for 12 (Ipomoea) or 42 (Stachytarpheta) days. Preliminary trials indicated that these periods were at least twice as long as the ones required for maximum germination of these species in the greenhouse. Seedlings were considered to have emerged after they had broken the soil surface. At the end of the experimental period, the leaf, stem and root dry weights of all emerged seedlings were recorded. The se data were used for the calculations of biomas $s$ allocation patterns: root, stem and leaf mass ratios (respectively, leaf, stem or root mass per unit of mass of whole plant, RMR, SMR and LMR).

\section{Statistical analysis}

For the germination experiments, each treatment was replicated five times in a completely randomized block design (osmotic stress) or a completely randomized design (light/nitrate). For the planting depth experiment, treatments were replicated four times in a completely randomized block design (each pot represented one replication of a given depth). The germination experiments were repeated once with similar results, the data of both experiments were pooled for presentation. Each data set was subjected to Levene's test for homogeneity of variance and to residual plots to check for homoscedasticity. Normal probability plots were constructed to examine the assumption of normality. When necessary, germination and emergence data were transformed by arsin (Raíz de y); no transformation was required for the biomass allocation data. Transformed data were retransformed for presentation. Data from the Planta Daninha, v. 14, n. 2, 1996. 
osmotic stress trial were subjected to regression analysis. Data from the other experiments were subjected to analysis of variance: within each species and experiment, treatment means were separated by single degree of freedom contrasts or by the Bonferroni's method of multiple comparison $(\mathrm{P}=0.05)$. Statistical analyses were performed by STATISTICA for Windows release 4.5 (STATISTICA for Windows, 1994) or SYSTAT Version 5.03 (Wilkinson, 1990).

\section{RESULTS AND DISCUSSION}

\section{Osmotic stress}

Both Ipomoea and Stachytarphela showed a similar response to increasing osmotic stress. Germination decreased linearly with decreasing osmotic potentials. Regression analysis performed on the accumulative percent germination throughout all experimental period confirmed the linear nature of the germination response in Ipomea $(\mathrm{Germ}=74.4$ $\left.+72.9 \mathrm{MPa} ; \mathrm{F}_{1,28}=231.05, \mathrm{P}<0.0001: \mathrm{R}^{2}=0.89\right)$ and Stachytarpheta $(\mathrm{Germ}=72.43+65.8 \mathrm{MPa}$; $\left.\mathrm{F}_{1} 1_{8}=164.3, P<0.0001: \mathrm{R} 2=0.85\right)$. For Ipomoea, no germination was observed when osmotic stress exceeded -0.8 $\mathrm{MPa}$, whereas Slachrtarphela seeds were able to germinate at $-1.0 \mathrm{MPa}$ (Figure 1). Related Ipomoea species have been shown to possess similar responses to increasing osmotic stress (Crowley \& Buchanan, 1980; Hoveland \& Buchanan, 1973).

Osmotic stress also affected germination timing of both species. Unstressed Ipomoea seed $(0 \mathrm{MPa})$ germinated faster, showing a maximum value at day two (Figure 1). Under osmotic stress, germination of Ipomoea was delayed, being maximum at $\mathrm{da}^{\mathrm{y}}$ four, for the $-0.2 \mathrm{MPa}$ treatment; at day six for the $-0.4 \mathrm{MPa}$ treatment, and at day eight for the -0.6 and $-0.8 \mathrm{MPa}$ treatments (Figure 1). For Stachytarpheta, germination of unstressed seeds was maximum at day 14, decreasing sharply at day 18 (Figure 1). Seeds incubated at -0.2 and $0.4 \mathrm{MPa}$ showed a plateau of maximum germination from day 10 to the end of the experiment, while germination of seeds from the -
0.6 to $-1.0 \mathrm{MPa}$ treatments was maximum at day 14, decreasing slightly thereafter (Figure 1).

Stachytarpheta showed a remarkable capacity to germinate under low osmotic potentials. This characteristic, together with its known physiological response to water stress (Dias Filho et al., 1995), may in part help to explain the occurrence of this and related species in overgrazed areas in pastures (Dias Filho, 1990; Haselwood \& Motter. 1983; Kleinschmidt \& Johnson, 1987). In these exposed areas, moisture content of the soil surface is subjected to a greater variability, and is normally lower than in adjacent areas protected by vegetation. Colonization of such areas is expected to be primarily by species capable to germinate and develop over a wide range of osmotic pressures.

\section{Light and nitrate}

Germination response to light indicated that Ipomoea seed was insensitive to light environment, while Stachvtarphela seed showed a positive photoblastic behavior (Figure 2). This suggests that management practices that help prevent seeds from receiving light, such as soil cultivation and mulching, could drastically reduce the occurrence of Slachylarphela, while no such effect would be observed for Ipomoea. Slachylarphela seeds that did not germinate in the dark were able to germinate normally once exposed to light (data not shown). This response suggests that the short term period (14 d) that the seed was deprived from light, under ideal moisture and temperature regimes, did not stimulate dormancy. Dormancy is known to be induced in this species in the field after long periods of incubation in the dark (M. B. Dias Filho, unpublished data).

Posl hoc contrasts showed that nitrate had a negative effect on germination of Ipomoea seed under both light $\left(\mathrm{F}_{1.24}=5.38 ; P=0.03\right)$ and dark $\left(\mathrm{F}_{1.24}=8.71 ; \mathrm{P}=0.007\right)$ conditions (Figure 2). For Stachvtarpheta, no effect of nitrate could be detected on the final seed germination in the light. 

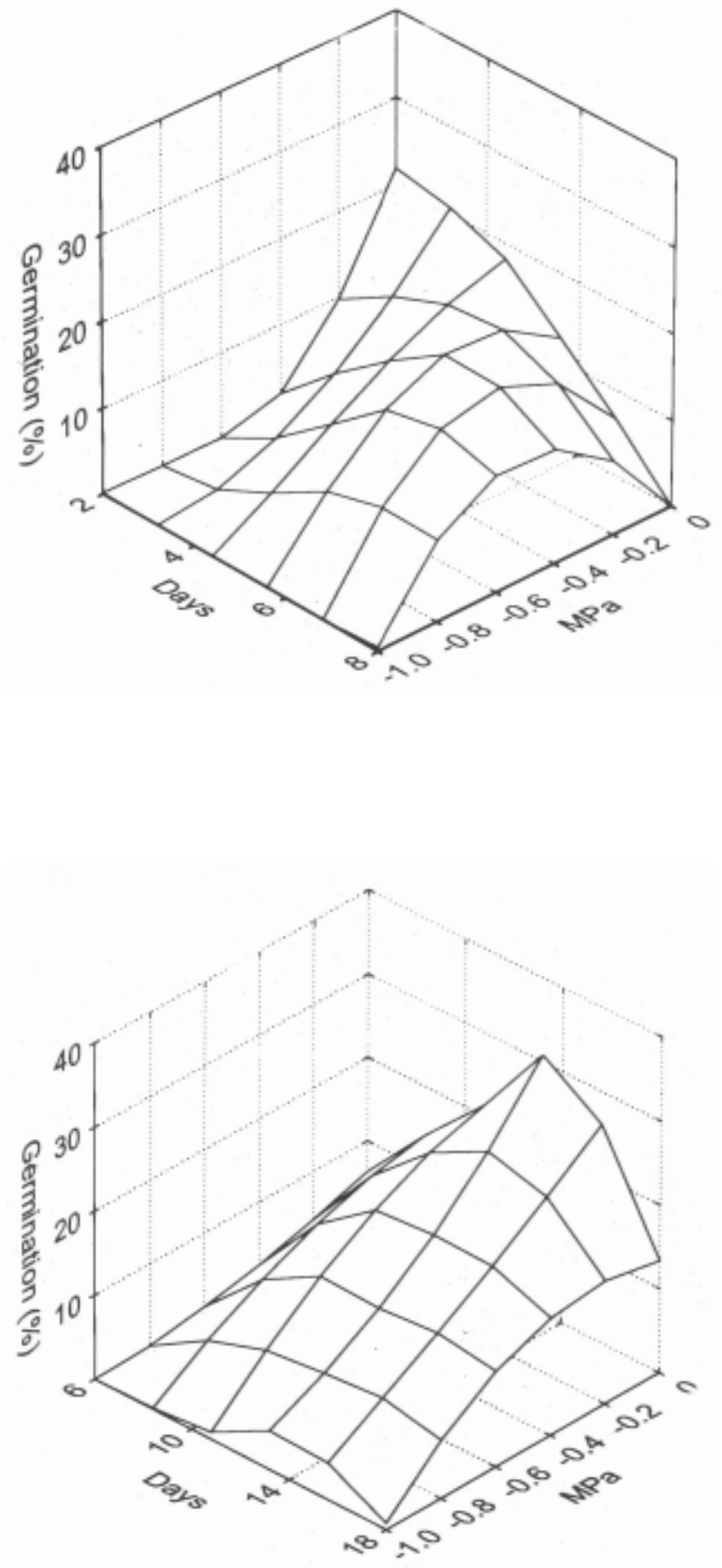

FIGURE 1. Effect of osmotic stress on the proportion of Ipomoea and Stachytarpheta seed germinating at different days after planting. Surfaces fitted by a bicubic spline smoothing procedure. 


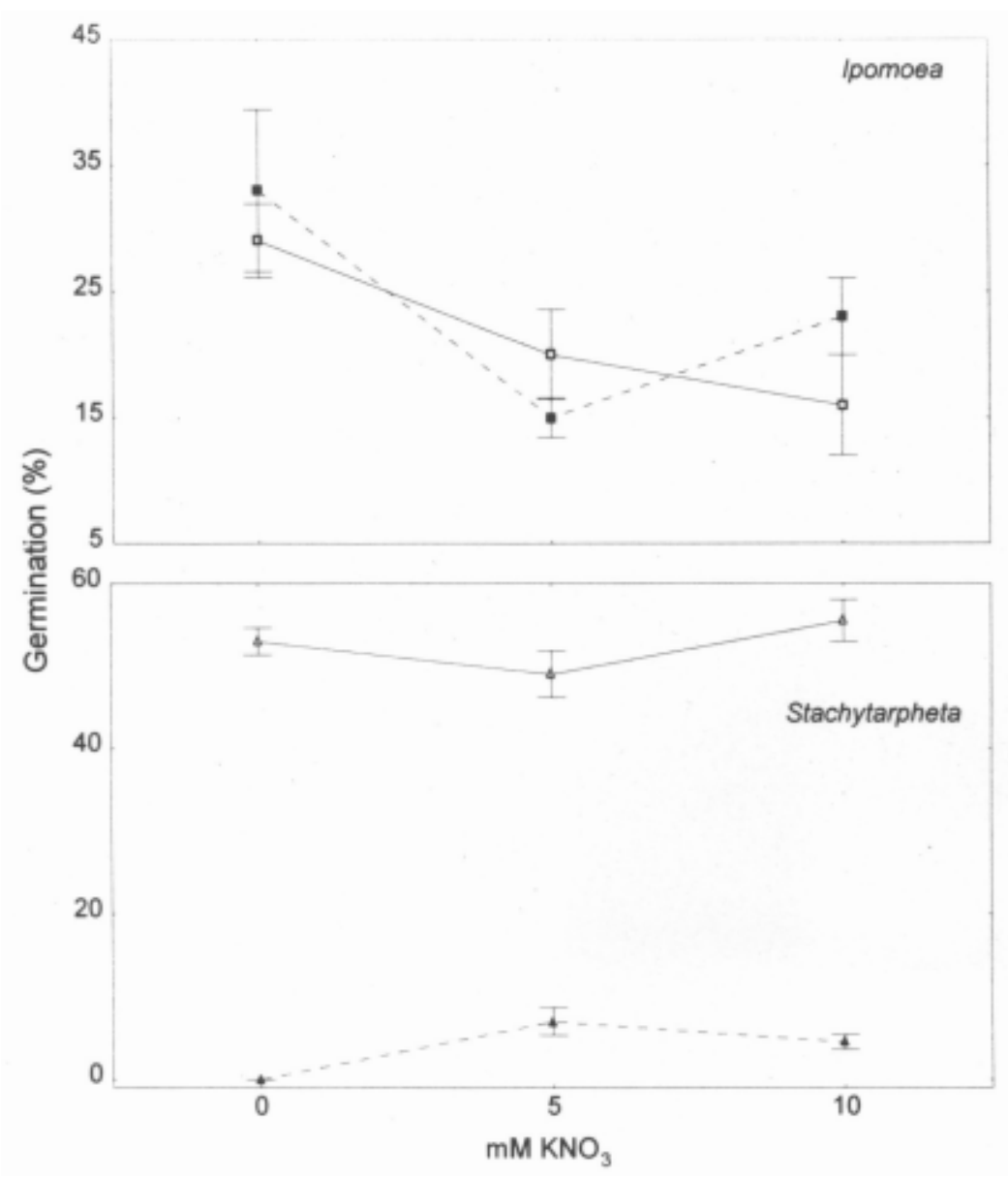

FIGURE 2. Effect of light and nitrate levels on percent germination of Ipomoea and Stachytarpheta, at seven (Ipomoea) or 14 (Stachytarpheta) days after planting. Each value is the mean of 20 seeds each, with five replications. Vertical bars are \pm 1 stand ard error of the mean. Light $=$ open symbols and solid lines: dark = closed symbols and dashed lines.

However, dark germination of this species was weakly, but significantly $\left(\mathrm{F}_{1,24}=6.37 ; \mathrm{P}=0.02\right)$ stimulated by nitrate (Figure 2). Germination stimulation by nitrate in the dark has been suggested to act like a "gap detection mechanism", an ecologically important characteristic that may enable buried seeds to sense the presence of nearby plants (Pons, 1989). The observed response of Stachytarpheta to nitrate in the dark may, to some extent, suggest the presence of such mechanism. This characteristic could be of a great adaptive significance for a small seeded species (seed mass
$=1.22 \pm 0.04 \mathrm{mg})$, with a relatively small seedling size and growth rate (M. B. Dias Filho, unpublished data) like Stachytarpheta, by decreasing the risks of an early competition for external resources with other plants.

\section{Planting depth}

No significant $(P>0.05)$ effect of planting depth could be detected on seedling emergence of Ipomoea (Figure 3). However, a tendency for lower emergence was observed for seed placed on the soil surface (Figure 3), probably due to poor see d-soil contact and desiccation. 


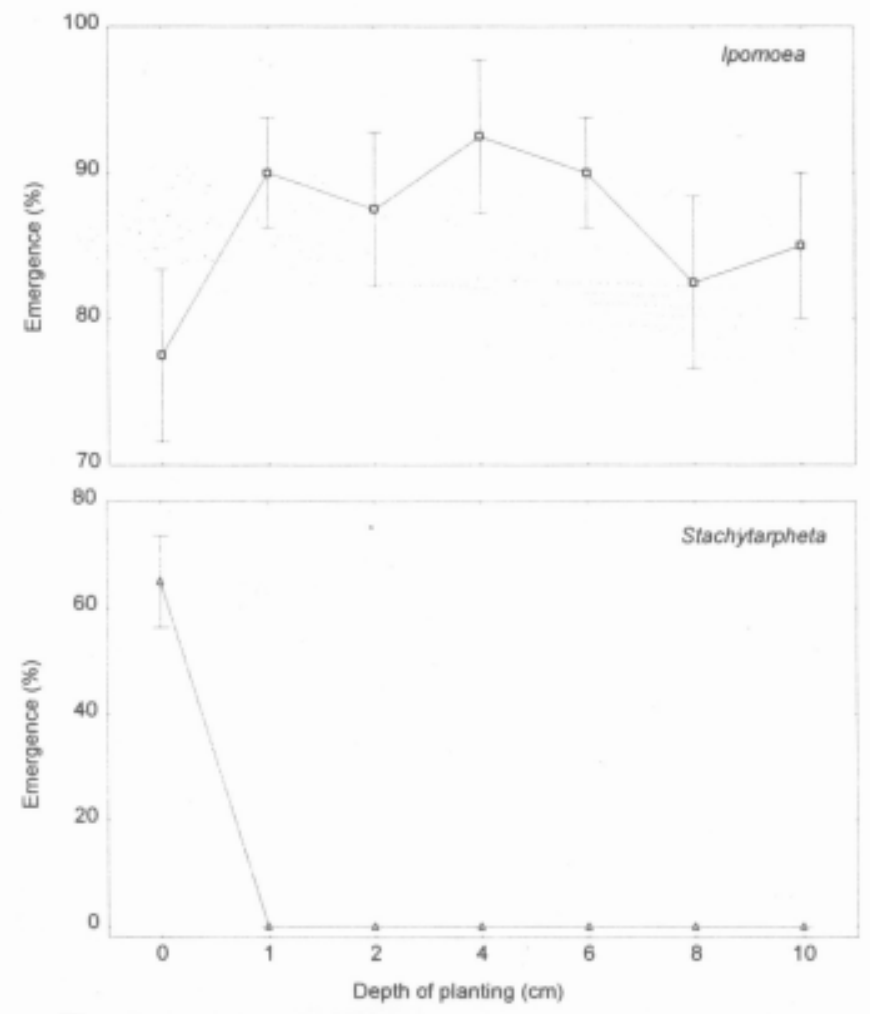

FIGURE 3. Effect of planting depth on percent emergence of Ipomoea and Stachytarpheta, at 12 (Ipo moea) or 42 (Stachytarpheta) days after planting. Each value is the mean of five (Ipomoea) or 10 (Stachytarpheta) seeds each, with four replications. Vertical bars are \pm 1 standard error of the mean.

Results from the osmotic stress (Figure 1) and light (Figure 2) trials corroborate the observed emergence response of Ipomoea to planting depth. Many Ipomoea species have also been reported to have the ability to emerge from relatively great depths (for a review see Elmore et al. 1990), a characteristic that, for the present species, must be re lated to the lack of light requirement for germination and to the relatively large seed mass $(64.31 \pm 1.49 \mathrm{mg})$. The observed emergence response of Ipomoea shows that this species, which has epigeal germination, has a great degree of plasticity with respect to hypocotyl extension when buried at different depths. Because in agricultural environments, conditions such as seed position in the soil profile may be constantly changing due to practices like cultivation and to biological agents, this characteristic may be considered of great adaptive significance for this species. Unlike Ipomoea, emergence in Stachytarpheta was restricted to seeds planted at the soil surface (Figure 3). This result agrees with the positive photoblastic nature of the seed of this species shown in the light experiment (Figure 2) and correlates with the natural occurrence of this species mainly on disturbed open areas like overgrazed pastures and road sides.

An important characteristic often overlooked in planting depth trials is the biomass allocation pattern of seedlings that emerge from different seeding depths. In the present study, the amount of biomass allocated to roots (RMR) by Ipomoea was significantly (Bonferroni's method, $P<0.006)$ higher for seedlings that emerged from depths up to $6 \mathrm{~cm}$, decreasing at greater depths (Figure 4). Biomass allocated to stems (SMR) and leaves (LMR) had a tendency to be similar for depths up to $2 \mathrm{~cm}$, respectively, increasing (SMR) 
or decreasing (LMR) at greater depths (Figure 4). These patterns suggest that emergence from greater depths compromises the ability of Ipomoea seedling to develo $\mathrm{p}$ rapidly roots and leaves, as during the early phase of seedling development, greater amounts of stored seed reserves had to be allocated to hy pocotyl elongation to enable the cotyledons to reach the soil surface. As a fast and efficient capture of above and below ground resources can be key for the survival and competitive ability of establishing seedlings (e.g., Harper, 1977; Fenner, 1987) it could be speculated that emerging from increasing depths may compromise the survival ability of Ip omoea se edlings by reducing the relative amount of biomass invested to leaves and roots, thus making these plants less capable to compete for external resources and, as a consequence, to endure and recover from stresses such as drought, mowing or herbivory.

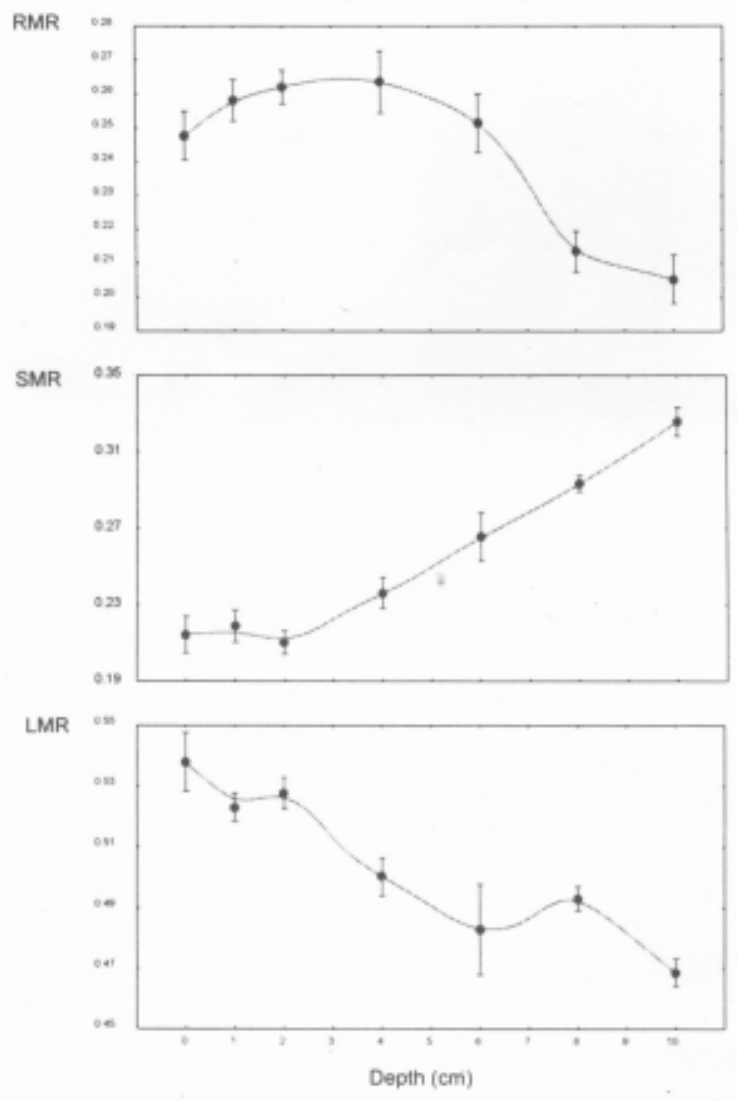

FIGURE 4. Biomass allocation to roots (RMR), stems (SMR) and leaves (LMR) of Ipomoea seedlings emerging from various depths. Vertical bars are \pm 1 standard error of the mean $(n=5)$. Curves fitted by distance-weighted least squares.

\section{ACKNOWLEDGMENTS}

To Katia F. Rodrigues for as sistance during the establishment of the experiments.
Sana Gardescu, Todd Daws on, Peter Marks and two anonymous reviewers provided valuable suggestions to improve this manuscript. 


\section{REFERENCES}

CROWLEY, R.H., BUCHANAN, G.A. Responses of Ipomoea spp. and smallflower morningglory (Jacquenontia tamnifolia) to temperature and osmotic stress. Weed Sci., v.28, p.87-82, 1980.

DIAS FILHO, M. B. Plan tas invaso ras em pastagens cultivadas da Amazônia: estratégias de manejo e controle. Belém: EMBRAPA-CPATU, $1990.103 \mathrm{p}$. (EMBRAPA-CPATU. Documentos, 54).

DIAS FILHO, M.B. How is fecundity affected by mowing in the tropical weed Stachytarpheta cayennensis (V er be nace ae). Pes qui. Agropecu. Bras., v.29, p.1675-1679, 1994.

DIAS FILHO, M.B., WISE, J.A., DAWSON, T.E. Irradiance and water deficit effects on gas exchange behavior of two C3 Amazonian weeds. Pesqui. Agropecu. Bras., v.30, p.319-325, 1995.

ELMORE, C.D., HURST, H.R., AUSTIN, D.F. Biology and control of morningglories (Ipomoea spp.). Revi. Weed Sci., v.5, p.83114, 1990.

EM ME RICH, W. E., HA RD EG REE, S. P. Polyethylene glycol solution contact effects on seed germination. Agron. J., v. 82, p.1103-1107, 1990.

FENNER, M. See dlings. New Phy tol., v. 106 (suppl.), p. 35-47, 1987.

HAR PER, J.L. Pop ula tio n biology of pla nts London: Academic Press, 1977. 892p.

HASELWOOD, E.L., MOTTER, G.G. Handbook of Hawaiian weeds. 2nd. ed. Honolulu: University of Hawaii Press. 1983, USA.
HOVELAND, C.S :, BUCHANAN, GA. Weed - seed germination under simulated drought.

Weed Sci., v.21, p.322-324, 1973.

KL EINS CHMIDT, H.E., JOHNS ON, R. W. Weeds of Queensland. Brisbane: Queensland Department of Primary Industries, 1987. 469p.

LORENZI, H. Plantas daninhas do Brasil: terrestres, aquáticas, parasitas, tóxicas e medicinais. 2.ed. Nova Odessa: Plantarum, 1991.440p.

NAIR, N.C., MOHANAN, C.N., SREEKUMAR, P.V. Stachytarpheta cayennens is (L. C. Rich) Schau. A new record for India and with a key to the Indian species. J. Bombay Nat. Hist. Soc., v.79, p.230-232, 1982.

PONS, T.L. Breaking of seed dormancy by nitrate as a gap detection mechanism. Ann. Bot., v.63, p.139-143, 1989.

SCHAFER, D.E., CHILCOTE, D.D. Factors influencing persistence and depletion in buried seed population. II The effects of soil temperature and moisture. Crop Sci., v.10, p.342-345, 1970.

SMITH, C.A., SHAW, D.R., NEWSON, L.J. Arrowleaf sida (Sida rhombifolia) and prickly sida (Sida spinosa): germination and emergence. Weed Res., v.32, p.103-109, 1992.

STATISTICA FOR WINDOWS General conven ti on s and statis tics $I$. Tuls a: StatSoft, Inc., 1994. v.1, 717p.

WILK INSON, L. SYSTAT: The system for statistics. Evanston: SYSTAT, Inc., 1990, 6'77p. 